\title{
PSYCHOLOGICAL EFFECTS OF ISLAMOPHOBIA ON HIJAB BAN VICTIMS IN TURKEY IN THE CONTEXT OF FEBRUARY, 28 HIJAB BAN PROCESS AND RELIGIOUS COPING
}

\author{
Research Article
}

Saliha Uysal*

Received: 14.12.2019

Accepted: 27.12.2019

\begin{abstract}
This study puts forth the state of intolerance against Muslim women wearing hijab in Turkey especially focusing on 'the process of February, 28' and establishes its significant effects on women with hijab and its development till today. Wearing hijab especially in public space has been a big problem in Turkey for the religious people in society. Although the positive developments in Turkish politics in 2008 and in 2013 which provided hijab liberty, today still Islamophobia is manifested clearly with concealed and revealed signs by the Islamophobic print media in Turkey. In this qualitative study 10 Turkish women with hijab who experienced 'the period of $28^{\text {th }}$ February' and the process after it were interviewed and the women were reached by snow-ball method. It can be said obviously the period of $28^{\text {th }}$ Feb was a trauma on women causing depression, lack of self-confidence, lack of trust towards people, anxiety, OCD. Some of these women had to have therapies and medicine. Some overcame with the issue with religious practices. The participants who had to study university abroad started to seek justice with the motivation of seeking for human rights and in this sense orientation to west started. While it was being expected to see that
\end{abstract}

\footnotetext{
* Dr., Istanbul University Theology Faculty, ervauysal@hotmail.com, ORCID: 0000-0003-0408-7775

For citation; Saliha Uysal, "Psychological Effects of Islamophobia on Hijab Ban Victims in Turkey in the Context of February, 28 Hijab Ban Process and Religious Coping”, Journal of The Near East University Islamic Research Center 5, no 2 (2019): 281-314, DOI: https://doi.org/10.32955/neu.istem.2019.5.2.03
} 
Islamophobia and hijab ban would isolate these women from society, as opposed to the expectations, Islamophobia which affected Turkey deeply provided a qualified workforce to academia, bureaucracy in Turkey in long term by educated women with hijab.

Keywords: Islamophobia, hijab ban, intolerance, hate crime, discrimination, Feb 28th.

\section{8 Şubat Başörtüsü Yasağı Süreci Bağlamında İslamofobinin Başörtüsü Yasağı Mağdurları Üzerindeki Psikolojik Etkileri ve Dini Başa Çıkma Öz}

Bu çalışma, özellikle 28 Şubat sürecine odaklanarak Türkiye'de başörtüsü takan Müslüman kadınlara karşı sergilenen tahammülsüzlüğü ortaya koymakta ve başörtüsü yasağının başörtüsü takan kadınlar üzerindeki etkilerini ve bugüne kadarki gelişimini aktarmaktadır. Türkiye'de özellikle kamusal alanda başörtüsü takmak dindar kesim için büyük bir problem olmuştur. 2008 ve 2013'te başörtüsü hürriyeti sağlayan Türk siyasetindeki olumlu gelişmelere rağmen halen, Türkiye'deki İslamofobik medyada İslamofobinin örtülü ve açık işaretleri görülmektedir. Bu nitel çalışmada 28 Şubat dönemini ve sonrasını tecrübe etmiş 10 başörtülü Türk kadını ile mülakat yapılmıştır, kadınlara kartopu yöntemiyle ulaşılmıştır. $\mathrm{Bu}$ araştırmayla 28 Şubat döneminin başörtülü kadınlar üzerinde depresyon, öz güven eksikliği, insanlara karşı güven eksikliği, kaygı bozukluğu ve OKB’ye neden olan bir travma etkisi yarattığı söylenebilir. Bu kadınların bazıları terapi almak ve ilaç kullanmak durumunda kalmıştır. Bazıları ise dinî pratiklerle sorunun üstesinden gelmiştir. Çoğu yurtdışında üniversite okumak zorunda kalan katılımcılar insan hakları arayışı motivasyonuyla haklarını arayarak Batıya yönelmeye başlamıştır. İslamofobinin ve başörtüsü yasağının başörtülü kadınları kamusal yaşamdan tard edeceği ve onların izolasyonlarını artıracağı beklenirken, beklenenin aksine Türkiye'yi derinden etkileyen İslamofobi uzun vadede Türkiye akademisi ve bürokrasisine eğitimli nitelikli örtülü kadın işgücü kazandırmıştır.

Anahtar Kelimeler: İslamofobi, başörtüsü yasağı, tahammülsüzlük, nefret suçu, ayrımcılık, 28 Şubat. 


\section{INTRODUCTION}

There have been many definitions for the term Islamophobia in many different books, journals, essays...etc. We understand the formation of words 'Islam' and Greek word 'phobos' ${ }^{1}$ as prejudice and racism against Muslims, ${ }^{2}$ in other words anti-Muslim racism, a hostility of Islam that perpetuates negative stereotypes resulting in bias, discrimination, and the marginalization and exclusion of Muslims from social, political, and civic life. It has always been difficult to cope with Islamophobia for muslims. We can say that one of the strategies to cope with Islamophobia is 'religious coping'. Here it would be better to mention that Pargament states 'coping like religion is a process, a search for significance in times of stress' ${ }^{3}$

Islamophobia's manifestations are different depending on the specific socio-historical and cultural contexts of the societies, but it is employed in discourse and is rooted in structural racisms and thus projects itself also into the popular opinion of Islam and Muslims and increase of hate crimes committed against Muslims. ${ }^{4}$ It is believed that the term Islamophobia was first used in 1910 in West Africa Islamic

${ }^{1}$ Azmi Aksoy, Yunanca Türkçe, Türkçe Yunanca Sözlük, (İstanbul: Alfa Yayınları, 2003), 536.

${ }^{2}$ Necmi Karslı, “İslamofobi’nin Psikolojik Olarak İncelenmesi (Studying Islamophobia as Psychologically)", Journal of Academic Researches in Religious Science 13, no 1 (2013): 80.

${ }^{3}$ Kenneth I. Pargament, The Psychology of Religion and Coping, (New York: The Guilford Press, 1997), 90; Also see: Halil Ekşi, "Başaçıkma, Dinî Başaçıkma ve Ruh Sağlığı Arasındaki İliş̧ki Üzerine Bir Araştırma”, (PhD diss., Uludag University, 2001), 19.

4 "Islamophobia and Muslim Minorities Studies" CIGA (Center For Islam and Global Affairs), IMMS. Accessed December 22, https://www.izu.edu.tr/en/ciga/about-us/departments/islamophobia-and-muslimminorities-studies-(imms). 
Studies by French orientalists, ${ }^{5}$ then in 1980 s and 1990s it was recognized in the Anglo-Saxon ${ }^{6}$ world as a term which was seen in Europe widely too. But also this attitude caused the relatively Islamophobic directors to behave as oppressive or to overestimate the own citizens of the Muslim country like Turkey. Although these Muslims have not committed anything wrong, only having hijab or being graduated from a religious school made them discriminated from social, educational, political, civic life. It could be openly seen that these effects shaped the debates on Muslims in Turkey.

Islamophobia trend effecting Turkey deeply provided qualified personnel to the bureaucracy and academia in long term in Turkey contrary to expectations; this mass who had to study abroad sought for their rights with the motivation of seeking for human rights and this also provided heading towards the West. While it was being expected that Islamophobia and hijab ban would expel the women wearing hijab from the society, the opposite has been experienced and it caused the consolidation of these women with the West.

Since Islamophobia, anti-Muslim racism has become a threat in the world and since it has effected Turkey like many other Muslim countries, it has been a need to address this problem and its effects on society and experiencers of discrimination even in their own countries like citizens of Turkey. So This paper is especially focusing on hijab-

\footnotetext{
5 Abdellali Hajjat and Maewan Mohammed, Islamophobie: Comment les élites françaises fabriquent le probleme musulman, (Paris: La Découverte, 2013), 18.

6 Ergin Ergül, "Islamophobia and The Counter-Terrorism Strategies", (IPHRC The Independent Permanent Human Rights Commission, 2017), 3 as cited in "Islamophobia: Hijab", Mohammed Moussaoui, Islamophobie ou racisme antimusulman? accessed April 21, 2015, http://www.atlasinfo.fr/Islamophobieouracisme-antimusulman_a53527.html.
} 
ban in Turkey. This will enrich the debate on racism in Turkey in specific. In Turkey Islamic movement, which raised by 1980s was seen as opponent to western modernism and Kemalist modernism. While Kemalist modernism saw religion as a phenomenon which needs to be modernized, Islamic opposition criticizes this and carries the worry of "How will we modernize?" ${ }^{7}$ So the Muslims squeezed between religion and Kemalist modernism found themselves in a complicated situation. ${ }^{8}$ In fact Islamic movement caused the forming of Muslim identity again collectively which was deleted from minds by modernism and also caused the occur of this identity as a social actor again. It gathered pace in ' $80 \mathrm{~s}$; but it started from ' $50 \mathrm{~s}$ with the civil society sees it relatively. ${ }^{9}$

Also when we look at before '50s, a decision in 1934 attracts attention which was about the responsibility of wearing chador and similar clothes was left to the control of local administrations. More civilized clothes like coats were asked to be preferred instead of chador. ${ }^{10}$ After this decision, chador and veil were banned. The ban was applied approximately in 35 cities. ${ }^{11}$ Although there were people who protested these, the government ruled that the people who wear chador, veil, etc. would be identified by police force and informed to head of civilian administration and be penalized 'from five liras fro

${ }^{7}$ Kenan Çayır, Türkiye'de İslamcllık ve İslami Edebiyat: Toplu Hidayet Söyleminden Yeni Bireysel Müslümanlıklara, (İstanbul: İstanbul Bilgi Üniversitesi Yayınları, 2008), 72.

${ }^{8}$ Haldun Gülalp, Kimlikler Siyaseti, (İstanbul: Metis Yayınları, 2003), 35.

${ }^{9}$ Nilüfer Göle, Modern Mahrem, (İstanbul: Metis Yayınları, 1991), 172.

10 Solgun, "Menemen Olayları Sonrasından İkinci Dünya Savaşına Türkiye'nin İç Güvenliği (1931-1939), 142.

11 Solgun, "Menemen Olayları Sonrasından İkinci Dünya Savaşına Türkiye’nin İç Güvenliği (1931-1939), 143. 
twenty-five liras' in 1937 to ensure unity in practicing. ${ }^{12}$ It can be said that all these penalties and intimidation policies in Single-Party period were to create a perception of political reaction. And in 1990s Turkish political situation was still not ready enough for political Islamic power output in the context of democracy.13

Wearing hijab ${ }^{14}$ especially in public space has been a big problem in Turkey all through the history for the religious people in society practicing Islam. When the subject is handled in the context of history, it is known that the intolerance arguments against hijab in Turkey started in $1927^{15}$ and continued in $1950 \mathrm{~s},{ }^{16}$ in 1967 after a protest ${ }^{17}$ occurred at Ankara University, Theology Faculty and also with the hijab ban decision by constitutional court in $1997 .^{18}$

12 Solgun, "Menemen Olayları Sonrasından İkinci Dünya Savaşına Türkiye'nin İç Güvenliği (1931-1939), 145 as cited in EGM Republic of Turkey General Directorate of Police Archive, no 13216-7/1, "Peçe, Çarşaf ve Peştamal Yasağ Hakkına Tamim".

13 Tunahan, "28 Şubat Süreci: Post-Modern Darbenin Sosyo-Politik Dinamikleri ve Toplum Desteği” Bilgi Sosyal Bilimler Dergisi 30 (Summer, 2015): 23-41.

${ }^{14}$ A hijab is essentially a scarf that women wrap around their head to show that they are devout and to shield them from the world's harsh realities. See: "Religious Freedom Is it a Human Right to Wear a Hijab or Head Scarf as a Muslim Woman?," Professor Cerone International Human Rights Ins., 66637, accessed: July 10, 2019, https://www.academia.edu/3093167/Religious_Freedom_Is it_a_Human_Right to Wear a Hijab or Head Scarf as a Muslim Woman.

15 It was decided to change the clothes of women to modern clothes. For details see: BCA (Prime Ministerial Archive of the Turkish Republic, 030.10.00.00.53.346.6, February 3, 1927; Sertaç Solgun, "Menemen Olayları Sonrasından İkinci Dünya Savaşına Türkiye'nin İç Güvenliği (1931-1939), (PhD diss., Istanbul University, 2010), 142.

16 Doctor Hümeyra Ökten was the first lady with hijab who tried to get into the hospital. She had a negative reaction and moved to Saudi Arabia.

${ }^{17}$ Hatice Babacan wanted to get into Ankara University, Theology Faculty with her hijab. After she was banned, a group of students started the protest. She was expelled from university then.

${ }^{18}$ MGK (Republic of Turkey Secretariat-General of The National Security Council) decisions were accepted in TBMM (The Grand National Assembly of Turkey) on March 14, 1997. 
In Turkey in 1990s in addition to the army saw itself as an institution which advocates the society and redound a new sense of morality to society with Kemalism principles against Islam which was seen as perilous to capture the control of society. ${ }^{19}$ The perception that secular sphere is under danger was created in the period of the crisis of politics in transformation after 1990 due to Islamophobia in international political business cycle and due to the worry of Shari'aPolitical Reaction in national frame. ${ }^{20}$

In this context it is understandable why Kemalist modernization is uncomfortable with Islamism which has the political configuration feature in Turkey. ${ }^{21}$ As a result of being annoyed with Islam, some decisions were made in order to decimate the visibility of Islam by an intervention to public spaces with the aim to restrain the development of Islamic part which can also be called as Anatolian bourgeois in society. ${ }^{22}$ Nationalization of Islam $^{23}$ which brings political tension ${ }^{24}$ was seen as a threat which leads up to build social

19 Eyup Sabri Çarmikli, "Caught Between Islam and the West: Secularism in the Kemalist Discourse” (PhD diss., Westminster University, 2011), 14, 108, 140-152.

20 Berat Bekir Özipek, "28 Şubat ve İslamcılar” in Modern Türkiye'de Siyasi Düşünce: Íslamcllık, Vol 6, ed. Yasin Aktay, (İstanbul: İletişim, 2005), 641.

${ }^{21}$ Kenan Çayır, Türkiye'de Íslamcılık ve Íslami Edebiyat: Toplu Hidayet Söyleminden Yeni Bireysel Müslümanlıklara, (İstanbul: İstanbul Bilgi Üniversitesi Yayınları, 2008), 72; Deniz Işıker, "Bir Zorunluluk Alanı Olarak İçerisi ve Dışarısı 28 Şubat ve Başörtülü Kadınlar: Bir Zihinsel ve Ruhsal Dönüşümün Anlatıl(a)mamış Hikayesi, (Inside and Outside as an Obligation Area February 28th and Women with Headscarf: Unexplain(able)ed Story of a Mental and Psychological Transformation)" (Master diss., İstanbul Bilgi University, 2011), 11.

${ }^{22}$ Davut Dursun, Demokratikleşemeyen Türkiye, (İstanbul: İşaret Yayınları, 1999), 67.

${ }^{23}$ It is mentioned as "National Islam" in Davut Dursun's book Devlet, Siyaset ve Toplum, (İstanbul: Emre Yayınlar1, 1996),133. With this concept we state that Nationalization of Islam is seen as a threat political Islamic power. With Political Islamic power it is tried to mean Pure Islam (shariah).

24 Nilüfer Göle, Melez Desenler: İslam ve Modernlik Üzerine, (İstanbul: Metris Yayınları, 2008), 13-14. 
demands with individual existence identity. In order to prevent this, a movement which was based on tripod of "military power" "secular part" and "media" was constituted. With this movement February 28th postmodern coup occurred which did not beware using the overbearing policy raising the polarization in society and being cruel against the visibility of Islam and representation of Islam in public space.

This manifestation caused discrimination, traumas, psychological problems even disorders, social devastations and it harmed the democratic values. It can be said that the reflections of Islamophobia in Turkey are consists of a modernized perception of reactionary applied in Single-Party period which aimed to expel the traces of Islam from public, political, cultural, educational fields and in order to reach this aim approves all violent and oppressive practices.

It must be stated here that discrimination in Turkey was shaped by political factors internal and also external based on Islamophobia abroad in 'the process of February $28^{\text {th }}$ ' and it is still tried to be shaped today. By positive developments in Turkish politics and by historical decision on February 9, 2008 ${ }^{25}$ and October 1, $2013^{26}$ which provided hijab liberty, the forbidder mentality situation has changed. But Although the official situation changed, still in 2019 the Islamophobic print media of Turkey, especially in the period of elections in March and June which was used as a time for polarization in society, it can

${ }^{25}$ Official Gazette of the Republic of Turkey, October 22, 2008, No 27032.

${ }^{26}$ Democratization Program 
be said that Islamophobia is manifested clearly with concealed and revealed signs.

The aim of this research is to show the reflections of Islamophobia in Turkey while investigating the personal and psychological effects of hijab-ban on hijab ban victims in the context of February $28^{\text {th }}$ process and religious coping. The signs of hidden Islamophobia and its continuing effects today based on February $28^{\text {th }}$ process encouraged us to study this subject.

\section{METHODOLOGY}

In this research 10 women were interviewed who experienced 'the period of February $28^{\text {th }}$, and after it. 5 of them interviewed face to face and 5 of them were reached via phone call and e-mails. 3 of the participants were interviewed in ISAM, ${ }^{27} 1$ in a restaurant and 1 in her house. Interviews were completed between 15 May-17 June 2019. Before and after the interviews two specialists are contacted related on the issue. The participants were reached by snowball method. The interviews were written down and categorized and by the end of June they were analyzed after all interviews were completed. And descriptive analysis is used to analyze the findings. Instead of using the names of the women, initials are preferred. Participants showed willingness to attend our study. They were so motivated to reply our questions. Two of the participants were emotionally affected. One of them cried while answering questions and it was really hard to calm her especially in the second half of the interview. We tried to calm her

${ }^{27}$ Turkiye Diyanet Foundation Centre for Islamic Studies. Scholars and researchers especially theologists go to ISAM very often in order to search and study. 
and stated that we share the grief with same feelings. Most of the interviews took half an hour, only the interview in which the participant cried for long took an hour. While investigating the effects of concealed and revealed signs of Islamophobia and the solution of ban, the transformation of women in society are also searched.

5 of the women studied in Turkey while 5 of them had to go abroad for their education because of hijab-ban in 'the period of $28^{\text {th }}$ Feb' in Turkey. The socioeconomic and psychological situation, marital status of the women and their occupations after 'the period of $28^{\text {th }}$ Feb' has been investigated. Since the research was done by a researcher who already experienced the $28^{\text {th }} \mathrm{Feb}$ period herself, it gave trust to the participants to express themselves clearly and share their thoughts and emotions. Consequently this qualitative study is a result of explanations reflecting emotional, mental traumas of women who experienced $28^{\text {th }}$ February devastation and Islamophobic treatments deeply.

\section{FINDINGS and ANALYSIS}

3.1 Discrimination, Marginalization, Exclusion From Social, Political, Educational and Civil Life

Under this title cases especially in education, employment and politics field will be analyzed in short through our interviews. Also some short examples published by media which created an oppressive psychological atmosphere will be shared. Many cases in education field were recorded.

Education Results of our interviews show that students are prejudiced. Some of the students had to study university abroad. Since 
$28^{\text {th }}$ Feb, many students studied in Germany, Vienna, USA, UK. Hate speeches are another important point that must be mentioned under the title of education. Hate speeches were recorded during graduation ceremonies like in a medicine faculty graduation organization. ${ }^{28}$ It can be said that it was an encouraging national, political intolerance or violence towards women with headscarf in education field. It can be stated from our participants who had negative experiences in education field:

HKK: "I lost one year of my high school education since I failed due to absence as a result of the prevention from walking in the school with my hijab."

"After I failed one year in high school, I lost all my friends and tried to adjust a new class after the ban was semi-removed from the high school. In the second year of high school, National security teacher didn't let us to take his class wearing our hijabs. I experienced the same horrible process that year again but than resolved. After graduation from the high school, I could not accomplish my childhood dreams, one of which was being a doctor, although I was among the first two hundred students in the general entrance exam (OSS). Being a theology faculty student at Marmara University, I had to wear an ugly hat on my hijab during my young ages of bachelor years was a horrible feeling."

AG: "the ban on hijab to enter the universities, even to university test the following year was totally disappointing. I felt they took a sledge hammer and demolished my hopes, dreams and future..." "You are like 17 years old and this heavy political climate place their dirty and accumulated hijab ban history on your shoulders. And these are your young rebellious days... Of course, I want to be myself. I want society to accept me as I am. I don't want people or government to tell me what to wear or not."

${ }^{28}$ One of the students hit the head of another student with hijab who was the most successful student at Medicine Faculty and she tried to take her hijab off saying "You do not deserve to graduate from this faculty" and put her hand on the hijabi student's mouth to close her mouth to stop her speech. 
ŞBİ: "I could not study in my country due to hijab-ban. Austria served me all Kindness for my Education Rights.”

BK: "Some of our friends left the school, some of them went abroad for education while the others went to the University taking off their hijabs or wearing wigs which was very humiliating."

FG: "Turkey has always become a country trying to be more modern and had a problem and an inferiority complex about religion in both of secular and religious people. I have always been a second-class person in my country because I wear scarf and I defend Islamic values in this form. This has never change on social scale. On educational level I have been prevented to have the fundamental education right in secondary school for I have been using scarf. I have been forced to take off my scarf by state. The students who did not take off their scarfs could not enter the school buildings through 4 years. In the same years IHL schools' graduates have been prevented to prefer any faculty except religious studies. Therefore I could not prefer the faculty I wanted to study. "

MT: "Just before I graduated from a religious high school, the government had imposed sanctions on these schools, as automatically marking down our exam scores should we want to study in any faculties rather than Islamic theology schools. And in those days, hijab ban at universities was already a common issue which was legitimised as a norm by the opposite side."

"An old lady once approached me, by pointing at the university nearby, spat out in an extremely vulgar and coarse tone: 'you are not and will never be permitted to access those institutions!"

EK: "I can never forget disdain of my lecturers just because of my peruka and hat on my head. They tried to make me enter the 'persuasion rooms'. Also I had hate crimes many times in the middle of streets for many times"

\section{Employment}

In the field of employment, discrimination is seen clearly. It occurs in interviews, not getting the job or losing jobs, employeremployee relations, promotions, working and off days, duties, 
practicing religion. Also mobbing is another point, which shows discrimination.

AG: "Being a hijabi, it was not easy to find any job. Even conservative people preferred non-hijabis at that time, in order not to reveal their conservative identity."

"I was feeling I do not belong where I work and certainly I am not welcomed anywhere."

"It was really hard to find a job, and when you found one, the employers would pay you low - knowing that you would have to accept because there are no jobs for you out there in the market- except for cleaning and service jobs."

BK: "We suffered a lot from this unjust ban. For example If you go to some places you would not be allowed or people would have disturbing glances at you. We could not go to schools we wanted or we could not choose the jobs we wanted."

ŞBİ: "I felt strong insufficiency effect from social life in Turkey" "When I returned from Austria after graduation from university in 2007 Istanbul I started working at an architecture office. My boss told me not to pray at office."

EK: "They took my education and employment rights for 6 years."

FGD: "I was a teacher and I was dismissed in 1999 because I was wearing a hijab."

\section{Politics}

When it is looked at the brief history of hijab ban in Turkey it can be said that Islamophobia was becoming mainstream being promoted by Islamophobic parties. It was a polarization of Turkish society until the law changed and current government became in power. For elections in June Islamophobic parties gave signals related to Islamophobia.

If another example is needed we can give the sentence said by the Prime Minister of the Coalition Government in February 28th period which is so important reflecting the political view of that 
period in order to obstruct a hijabi deputy not to take her oath of office in Grand National Assembly of Turkey. In fact the Prime Minister's sentence "Please bring this woman into line!" had the meaning to expel this deputy elected by nation from the parliament which is a place for representation of national will.

This sentence also showed the intolerance of politicians of the period against hijab. One of our participants in this study tells about this intolerance and changeable political practices for hijab:

SS: "Hijab ban has been raised from time to time throughout history in Turkey. Headscarf is seen as a matter of regime whereas the headscarf is a fundamental human right. There is no headscarf ban in Turkey today, but there's no guarantee for tomorrow. It completely depends on the worldview of politicians. We need a social consensus to solve the hijab problem forever. Because there is no ban today but most of the private companies don't allow their employees to wear headscarf."

\section{Media}

When chronologic affairs are investigated it is seen that the problem of hijab which seems as if it has had a solution still continues as means of a psychological war for Islamophobia in Turkey.

\section{July 16, 1995}

The period which started with the ban of chador and veil in 1930s got into another aspect in which headscarves of hijabi students who were top of their classes/faculties were taken off by force in 1995.

In Sivas Cumhuriyet University Medicine Faculty the student with hijab who took the first place was not accepted to attend the graduation ceremony and one of the other students closed her mouth 
with her hands and stopped her saying: "You do not have right to attend this graduation."

\section{February 28, 1997}

The same mentality which started from universities and seen in secondary schools as well as public space also occurred at classes by not allowing hijabi students to enter classes with hijab in ReligiousVocational Schools which presence exists because of hijabi students. Identically a funny application called "coefficient application" was signed in order to prevent these students who graduated from Religious-Vocational Schools from studying at universities and faculties they desire like engineering, medicine...etc.

\section{June, 2019}

This process that we tried to explain with symbolic examples which were reflected with some cases in media finds its return today in civil life as it can be seen in many different photos on media.

In June 2019 at Eid al- Fitr, in İzmir Alaçatı one of the holiday alternative places in Turkey a lady with headscarf and hijood was tried to be kicked out from a beach although she had booked her place much earlier and had paid already 400 Turkish liras for her 8-member family booking. She was said there is no place for her on the beach. It was a clear discrimination and intolerance against hijab.

\section{Justice}

There were numbers of lawsuits brought. Even the number of victims show perceptibly the point where hostility against Islam and religious discrimination based on hijab reached. By contrast with this, it should be stated that Turkey gives asylum to the opportunity to seek 
justice for victims. In the justice system important court proceedings are continuing.

\subsection{Hate Crimes Towards Participants}

As it is known well that hate crime is defined as an offense in which the victim is targeted because of the actual or perceived race, color, religion, disability, sexual orientation, or national origin of that victim. ${ }^{29}$ The definition by Sullaway of hate crime that has been accepted internationally is an ordinary event, which was experienced very often by hijabi women in Turkey in 1990s. Moreover the intensive military and political oppression with bombardment of discriminatory media caused committing this offence as well as causing separations among family members in Turkey.

As some of our participants stated hijabi women were offended to take their hijabs off by their own family members, relatives even some of them were assaulted. It could be shared as our participants tell about this issue:

AG: "I remember an extended relative pulling off my hijab during a gathering when I was greeting them."

BK: "My cousin's engagement ceremony took place in a military wedding hole and I could not join." "In the University some of the teachers would humiliate us in class. Even one of them tried to take off my hijab in her private room."

FG: "I have experienced verbal abuses." "In Turkey seculars have always seen Muslims uneducated, uncivilized and rude one. They wanted to suppress religious people."

ZB: "once, a man held me by the arm and used physical violence and insulted me. another time, a woman yelled at me spitting towards my face. these

29 Megan Sullaway, "Psychological Perspective On Hate Crime Laws" Psychology, Public Policy and Law 10, No 3 (2004): 250. 
were the physical harassments I had experienced. Apart from these, I have been repeatedly subjected to verbal abuse."

HKK: "I was raised in a secular neighborhood in Istanbul, Kadikoy, while walking in the streets, I have been insulted many times by secularist and leftist people around."

"While I was protesting the hijab ban in my first year of high school, at the age of 15, one police officer started to kick me and tried to take my hijab forcefully. My father told the officer to stop doing that then he was arrested and jailed together with 4 other innocent parents. The moment Ahmet Hakan announced that my father was jailed not only arrested And the first visit that I gave to my father in the prison are unforgettable."

FGD: "I knew that I would be dismissed when I was a teacher in a village. That's why I was telling my managers not to try for me and put themselves in danger since I would not take my hijab off. One day a visiting officer would come to identify me. No one was looking at my face, in the school the boss was escaping from me. But even when I saw the cleaners at school tried to turn their eyes' away from me. Whoever was in contact with us saw themselves in danger. Everyone was behaving us as if we were stricken with plug. I can never forget this. My best friend was a secular colleague. Only she was a good friend to me. The boss was telling me: 'If it is in my hand, I would not allow you to enter this village. Where do you get this courage from. There must be a political terrorist group behind you' So there was an oppression on us".

\subsection{Thoughts of Participants on Development of}

\section{Discrimination and Islamophobia in Turkey}

Certainly in these interviews with participants the most remarkable comments summarize the experiences of the process obviously and clearly.

AG: “In my opinion Islamophobia was worse during those days of hijab ban. Now what I see in society is polarization. Before they were stereotypical about so many things about Islam. I mean the white Turks, they had no idea of Islam - they were totally ignorant. Islam meant Iran or Saudi Arabia for them. 
During AK Party leadership, a lot has changed in the past decade. They saw that hijabis and conservative people also can speak foreign languages (many, like me have returned country), they saw that we can lead a modern life too, that we are educated and open minded. So their ignorance had turned into hostility and hatred towards hijabis."

ZB: "I think that with the legal regulations, the prohibition has been physically exceeded but it is still psychological. The headscarf ban is a human rights issue, and strictly laws should be protected. but I think the issue of participation in life and sociological acceptance outside the ban is troubling."

HKK: "It is an unfortunate subtle and ironic war of some leftist allegedly Muslim governors against practicing Muslims. Most probably it is a nonsense tool of western production to modernize the world. Even before the republican period, modernizing women was one of the major project of Ottoman Empire, so Kemalist movements against hijab is a predictable phase of this process."

ŞBI: "Hijab-ban was only nonsense of the Government that time and Politicians at all."

MT: "Hijab is the last castle that we should stand up for. Unless we strive for its preservation, our values are liable to be led astray by destructive forces of secular powers and we will end up standing in the conundrum of being facsimiles of materialistic men.

They want to extinguish the light of Allah with their mouths, but Allah will perfect His light, although the disbelievers dislike it. - 61:8"

EK: "Hijab ban took women's dreams from their hands like it did to me. It caused to obligatory life directions. Education, employment rights and psychological health are taken from the hands of women for one generation"

FGD: "Because of those days that we could not do something else, we made wrong decisions for wrong marriages." 


\subsection{Psychological Problems Experienced by Participants}

It is known that psychological disorders ${ }^{30}$ like anxiety disorder, ${ }^{31}$ depression, ${ }^{32}$ post-traumatic stress disorder ${ }^{33} \mathrm{OCD},{ }^{34}$ can occur on victims of trauma. ${ }^{35}$ When we classify the reasons of psychological disorders it can be easily seen that there are biological, organic and psychological factors. It difficult to discuss all these

30 A psychological disorder is a condition characterized by abnormal thoughts, feelings, and behaviors. See: , 548.

31 The category anxiety disorder includes five primary types: generalized anxiety, panic attacks, phobias, obsessive-compulsiveness and post-traumatic stress. See: Dennis Krebs and Roger Blackman, Psychology: A First Encounter, (San Diego: Harcourt Brace Jovanovich Publishers, 1988), 704.

32 Depression may mean anything from temporarily feeling 'down' to being so debiliated as to be unable to move or speak. See: Rowan Bayne et al., The Counsellor's Handbook: A Practical Guide to Professional and Clinical Practice, (London: Chapman \& Hall, 1994), 44; for details see Özcan Köknel, Depresyon: Ruhsal Çöküntü, (İstanbul: Altın Kitaplar Yayınevi, 1989), s. 72-212.

${ }^{33}$ DSM III introduced it as a new category. As the name implies, it occurs after traumatic experiences...The disorder may occur immediately following a traumatic experience or weeks, months and even years later. See: Krebs and Blackman, Psychology: A First Encounter, 707-708.

${ }^{34}$ In diagnostic criteria of DSM-IV, "the obsessive-compulsive personality disorder is characterized by a pervasive pattern of preoccupation with orderliness, perfectionism and mental and interpersonal control, at the expense of flexibility, openness, and efficiency. It is present in a variety of contexts, as indicated by at least five of the following criteria: 1-preoccupation with details, rules, lists, order, organization, or schedules to the extent that the major point of the activity is lost. 2Perfectionism that interferes with task completion. 3-Excessive devotion to work and productivity to the exclusion of leisure activities and friendships 4overconscientiousness, scrupulousness, and inflexibility about matters of morality, ethics, or values 5-inability to discard worn-out or worthless objects even when they have no sentimental value 6- reluctant to delegate tasks or to work with others unless they submit to exactly his or her way of doing things. 7- Adopts a miserly spending style toward both self and others; money is viewed as something to be hoarded for future catastrophes 8- Rigidity and stubbornness". For more details see: Jan Derksen, Personality Disorders: Clinical And Social Perspectives: Assessment and treatment based on DSM-IV and ICD-10, (Chichester: John Willey and Sons Inc., 1995), 107-115; obsessions are persistent, recurring thoughts; compulsions are irresistible urges to engage in particular behaviors. People may suffer from obsessions and compulsions separately or in concert. See: Krebs and Blackman, Psychology: A First Encounter,705.

35 İsmail Özgür Can et al., "Travma Mağdurlarında Ruhsal Travma Bulguları (Mental Findings in Trauma Victims)", Archives of Neuropsychiatry, (2013): 231. 
factors here but at least we can mention about the psychological factors due to our research topic, which play an important role in the occurrence of psychological disorders. In psychological factors among the facts there are neurotic parents, dissension in family, lack of identification examples, education system, stability of education, preference of vocation without conflicts; heavy spiritual traumas, frustration...etc. Although these components might seem that they don't have any pathological value in the beginning but summation of any of them might seed the neurosis or psychosis in long term. Among spiritual traumas we can mention the loss of relatives, loss of wealth, loss of homeland, loss of honor and loss of any object ${ }^{36}$ that the individual loves and cares. ${ }^{37}$ Also factors like value judgements, religious and political pressure, discrimination might cause loss of self-confidence, stress, inferiority complex as well as other psychological problems and disorders. It can be said that there is a relation between culture and disorders. ${ }^{38}$ Regarding being discriminated based on religious identity, it can be said that the period of $28^{\text {th }}$ Feb was a big trauma ${ }^{39}$ on our participants with hijab. Our participants state their troubles as in below:

\footnotetext{
${ }^{36}$ Rasim Adasal, Ruh Hastallklarl, (Ankara: Ankara Üniversitesi Basım Evi,1996), 24.

${ }^{37}$ Religious objects can be listed like hijab as well among these factors.

${ }^{38}$ Adasal, Ruh Hastaliklarl, 24-25.

39 It was the first diagnosis which determined trauma as a cause of psychiatric disorders. The psychological consequences of trauma studies in psychiatry were influenced by many political and cultural processes. The studies of trauma had a history of cycle including the pauses for a long time. The history of trauma had an interesting story in psychiatry which is an example demonstrating the big changes of psychiatric diseases. Also the relations between trauma and psychiatric disorders had significant changes in DSM over the last 60 years. So that trauma holds an important place in psychiatry practice. See: Ahmet Kokurcan and Hüseyin Hamdi Özsan, "Travma Kavramının Psikiyatri Tarihindeki Seyri (The Course of The Trauma
} 
AG: "I think my biggest trauma was being deprived of my rights for education. This is a human rights violation and possibly the worst thing you would do to a teenager who is set to start university."

"you have this phobia that they look down on you"

ZB: "It effected my life and my psychology." "I lost my self-confidence, I had difficulty to sleep for long years." "I had psychological treatment and used medicine for a while."

EK: "I was in depression but I did not accept taking medicine or therapy. Even therapy was sth luxury for us."

FGD: "When I was dismissed I did not understand I was effected psychologically but later when I was back to my job in 2007, my friends and I had to send letters to Government in order to take our rights back from past between 2007 2012 continuously. When I got my rights back I understood that my psychology was effected a lot. Until that time I was standing upright believing that it was a dawa and we are the soldiers of that dawa. I was crying a lot."

Consequently it was inevitable that the hijab ban trauma brought depression, lack of self-confidence, lack of trust towards other people, anxiety disorder and OCD to hijabi women. Certainly, some of these women had to have therapies and medicine by doctors' advice. Some of them tried to overcome it with religious coping as it is mentioned in detail under the title of 'Role of Religion in Coping for the Participants'.

\subsection{Role of Religion in Coping for the Participants}

In stressful circumstances people are in search for some methods or ways to cope. These ways can be classified in many different groups. Among these groups it is very important to set forth the contribution of religion in the context of religious coping, which

Concept Throughout the History of Psychiatry)", Kriz Dergisi (Journal of Crisis) 20, no 1 (2012): 19-24. 
has an important place in lives of many of the people. Religion directs people through difficult times it provides guidance about where to go and how to get there. ${ }^{40}$ So religious coping ${ }^{41}$ is one of these ways to overcome stressful circumstances; in fact it is more than being a way since religion is fully involved with coping. Religious coping provides a very considerable starting point.

In coping people struggle in their life to reach the result of getting intimacy, emotional ease, personal development...etc. Beliefs, rituals, relations are all the ways to reach these results. When it is focused on the nature of coping as a process, it is seen that there are eight assumptions in this process: 1-People look for significance 2Events are constructed in terms of their significance to people 3People bring an orienting system to the coping process 4-People translate the orienting system into specific methods of coping. 5people seek significance in coping through the mechanisms of conservation and transformation 6-people cope in ways that are compelling to them.7-coping is embedded in culture 8-The keys to good coping lie in the outcomes and the process. ${ }^{42}$

Also when it is discussed problem-solving in the context of coping it would be better to mention problem-solving styles.

${ }^{40}$ Kenneth I. Pargament, The Psychology of Religion and Coping, (New York: The Guilford Press, 1997), 6, 90, 132.

${ }^{41}$ Religious coping is defined as the extent to which persons use religious beliefs and practices to help them to cope. See: Harold G. Koenig, Debra K. Weiner and Bercedis L. Peterson, "Religious Coping in the Nursing Home: A Biopsychological Model", The International Journal of Psychiatry in Medicine 27, no 4 (1997): 365376; Naci Kula, Bedensel Engellilik ve Dini Başa Çıkma, (İstanbul: DEM Yayınları, 2005), 59.

42 Ekşi, "Başaçıkma, Dinî Başaçıkma ve Ruh Sağlığı Arasındaki İlişsi Üzerine Bir Araştırma ", 26; Pargament, The Psychology of Religion and Coping, 90-119. 
Pargament and his colleagues tried to develop a scale for problemsolving styles and with their study they set forth that religious coping has three different ways. These religious coping styles are:

-Active personal exchange with God (collobarative) $;{ }^{43}$

-Solutions from God (deferring) and;

-Emphasizing the freedom God gives people to direct their own lives appeared to be an active coping orientation that stressed personal agency (self-directing). ${ }^{44}$

When people face with stressful issues religious coping might be beneficial or harmful or apathetic since religious coping is multipurpose. ${ }^{45} \mathrm{We}$ will mention positive sides of it here due to positive religious coping strategies that provided personal growth and success to our participants. Religious coping may provide comfort, stimulate personal growth, enhance a sense of intimacy with God, facilitate closeness with others or offer meaning and purpose in life. ${ }^{46}$ In other words when it is looked at the contribution of religion in coping process from a psychological perspective features and functions of religion like meaning, benevolent religious reappraisal, self-actualization, religious forgiveness, seeking spiritual support,

${ }^{43}$ Appeared to be part of internalized committed form of religion, one holding positive implications for the competence of the individual.

${ }^{44}$ K. I. Pargament et al. "Religion and the problem- Solving Process: Three styles of coping”, Journal for the Scientific Study of Religion, 27 no 1, 90-104; Ekşi, "Başaçıkma, Dinî Başaçıkma ve Ruh Sağlığı Arasındaki İlişki Üzerine Bir Araştırma ”, 26; Pargament, The Psychology of Religion and Coping, 27.

45 Kenneth I. Pargament and C. R. Brant, " Religion and Coping” in Handbook of Religion and Mental Health, edt. Harold G. Koenig, (USA: Academic Press, 1998): 118; Ekşi, "Başaçıkma, Dinî Başaçıkma ve Ruh Sağlığı Arasındaki İlişki Üzerine Bir Araştırma ", 28.

46 Pargament and Brant, " Religion and Coping”, Handbook of Religion and Mental Health, 118 
spiritual connection, religious purification, collaborative religious coping ${ }^{47}$ come into prominence.

In this study our participants who wear hijab because of their religious beliefs found religion as their best support against the religious racism and discrimination that they experienced. Consequently these women who became victims losing their rights heavily in a wide field from education to politics in 90s state that they overcame that hard period with their strong loyalty and belief in God.

AG: "I put my trust to Allah that He will open a door for me. Our religion promises glad tidings to those who are patient. So I did what I could do in my personal capacity, my everyday battles in the society and the country - then Alhamdulillah I got acceptance to an international university overseas with a scholarship. Surely this is Allah's blessings for the patience of such young teenagers who became a lot mature than their age due to this political climate in Turkey."

BK: "I believed in Allah and that He saw everything. I prayed a lot and believed Allah will help us."

ZB: "I tried to keep the relationship between God and me strong, and it gave me strength."

HKK: "During the ban in high school, more than an hour before I sleep, I was praying. I never lost my hope about that tomorrow will be better than today, since Allah would help us in our war against this dhulum."

ŞBİ: "Believing Justice of Allah for Past, Present and Future helped me to overcome the discrimination's effects."

EK: "My belief in Allah made me stand in that long period. I was praying, contemplating"

${ }^{47}$ Kenneth I. Pargament et al. "Patterns of Positive and Negative Religious Coping with Major Life Stressors", Journal for the Scientific Study of Religion 37, no 4 (1998): 710-711. 
FGD: "I was standing powerfully because I believed that I was doing something correct for my religion. I was a teacher in a village surrounded with high mountains. I was telling my self I wear hijab for the ridha of Allah who created these mountains. " [She can not stop her tears]

As it is seen in above religious reframing was able to transform this suffering hijab ban event into explainable and acceptable experience with salient or potential value and significance especially the ban could be religiously reframed as part of God's plan and thus be transformed into benign events since stressful life events can also be positively 'a test from God' 'a gift from God' 'an opportunity to get closer to God'. ${ }^{48}$ Our participants viewed this suffering event from a spiritual lens so it inversed to a positive, meaningful manner.

In other words which we can see the signs of it below suffering participants reinterpreted the event seeing it as another door that God opened for them studying abroad and they eventually achieved personal growth and success. Correspondingly Islamophobia trend which affected Turkey deeply provided qualified personnel to the bureaucracy and academia in long term in Turkey contrary to expectations. Because these women with hijab overcame the problem with religious coping and also they wanted to seek for their rights, they wanted to fight back as it can be seen in the example of AG case in our interview:

AG: "First it was kind of withdrawal due to disappointment. Then you feel the need to fight back that you can't keep quiet forever. So you look for ways for inclusion, you wanna say like I am still here - though you wanna ignore me and people like me- but we still exist and you have to accept us. Then the struggle begins

${ }^{48}$ Jianbin Xu, "Pargament's Theory of Religious Coping: Implications for Spiritually Sensitive Social Work Practice", British Journal of Social Work, 46/5(July 2016): 1394-1410. 
in your everyday life. Being called names, being looked down, stared at etc. You constantly have to prove them that you are different, not as the hijabi they have in their minds-stereotyped about."

ŞBİ: “T.C Government didn't allow me to study at University with my Hijab. Therefore in 2000 I had to move to Austria to study at Technical University in Vienna. I finished my Univertisty Education with Honorary Note in 2007 with Master's Degree."

As a result it is seen that religion is inseparable from societal views of proper behavior, psychological wellbeing, and the meaning of suffering ${ }^{49}$ and in this study our participants reported that religion was helpful in coping with their situations. Although the psychological problems etc. our participants found a new realm of meaning and success after hijab ban process, so their hard reality converted into congenial challenges.

\section{CONCLUSION}

Islamophobia stream which started abroad caused the secular administrators in Muslim countries like in Turkey to behave oppressive. It should be stated that examples of Islamophobic attitudes, hate crimes, mobbing...etc. are not few in Turkey. Only a small number of these incidents are revealed and mentioned here slightly as much as the participants shared. Especially, in $28^{\text {th }} \mathrm{Feb}$ period to express hostility and intolerance against women wearing hijab was very common. The general picture presented here shows that intolerance and discrimination against practicing women with

49 David R. Johnson and Joseph Westermeyer, "Psychiatric Therapies Influenced by Religious Movements", Psychiatry and Religion: The Convergence of Mind and Spirit, ed., James K. Boehnlein, (Washington: American Psychiatric Press Inc., 2000), 105. 
hijab in social, civic, educational, political life was at a serious level in the period of 28th February. It seems that the Islamophobic media tried to grow this discrimination and intolerance within parts of civil society. One sphere of media has been working to bring attention to the rise in hate crime towards Muslim women with hijab in society. Intolerance towards these women can enable a climate fostering crimes against practicing women and isolate them from the different spheres of society. Governmental, nongovernmental, national and international organizations, religious institutions, associations can challenge this kind of discrimination, isolation, intolerance and hate crimes against Muslims.

Muslim women in Turkey wearing hijab reported that they were discriminated based on their religious identity. With this study it can be said obviously the period of $28^{\text {th }}$ Feb was a trauma on women with hijab. This trauma brought psychological disorders like depression, lack of self-confidence, lack of trust towards people, anxiety, OCD. Some of these women had therapies and medicine. Some overcame with the issue with religious practices like prayers, contemplation and dhikr. It is too difficult to state the emotions, traumas of thousands of women here in this study and generalize it but we wanted to share at least ten of them which are alike to those thousands. It is known that in many studies women stated that they do not feel themselves as normal after hijab ban and they believe that hijab ban left them a heritage to get involved to a certain identity. ${ }^{50}$ But it is discovered that these women who were isolated in order to be expelled from society have a strong fighting soul; they are so

${ }^{50}$ Işıker, 'Bir Zorunluluk Alanı Olarak İçerisi ve Dışarısı”, 184. 
successful despite all obstacles in the fields, which they were expelled. It is seen that they are so strong, contendor in social, civic, educational, bureaucratic fields.

In conclusion Islamophobia, which affected Turkey deeply provided qualified work power of women with hijab to academia, bureaucracy in Turkey in long term. These women who had to study university abroad started to seek justice with the motivation of seeking for human rights and in this sense orientation to west started. While it was being expected to see that Islamophobia and hijab ban would isolate the women with hijab from society and that it would work up their isolation more, as opposed to expectations it caused the integration of these banned women with modernization.

\section{RECOMMENDATIONS}

If permanent measures are not taken regarding eradicating the roots of Islamophobia, serious social problems will continue to be experienced. Especially, discrimination against women wearing hijab poses a great risk to the democratic foundations and social peace. In order to provide the social peace and tranquility the following policy recommendations should be stated in order to struggle Islamophobia effectively:

- Awareness in public for human rights, belief and religion freedom should be raised by media, politicians and NGOs.

- Awareness about Islamic freedom such as Islamic clothes, praying etc. in social and civic life as in education, employment fields should be raised. 
- While raising awareness it must be underlined that discrimination for hijab as the most important expression of Islamophobia does not arise from Turkish society. Especially it should be highlighted that hijab discrimination is in an external form as a natural result of cultural alienation.

- The government in future is called upon to respect the international standards of tolerance and nondiscrimination.

- Laws must be protected not to change that provides tolerance and non-discrimination against women with hijab. Hijab-ban should be acknowledged as a discrimination-crime.

- A law should be adopted for public officials at any level who use statements inciting violence and discrimination against women wearing hijab.

- Public officials at any level who oppose the discrimination against Muslim women wearing hijab should put in a more visible position in media.

- Documentaries, films should be produced to make the public not to forget the hijab ban and its results on society.

- The countries in Europe which show tolerance and nondiscrimination should be given as examples in media.

- Advertisements, movies, songs, documentaries, cartoons aimed at encouraging mercy, tolerance to others should be produced.

\author{
Funding: "NO" \\ Conflicts of Interest: "NO"
}




\section{REFERENCES}

Adasal, Rasim. Ruh Hastalıkları. Ankara: Ankara Üniversitesi Basım Evi, 1996.

Aksoy, Azmi. Yunanca Türkçe, Türkçe Yunanca Sözlük. İstanbul: Alfa Yayınları, 2003.

Bayne, Rowan et al. The Counsellor's Handbook: A Practical Guide to Professional and Clinical Practice. London: Chapman \& Hall, 1994.

Bayrakl1, Enes and Hafez, Farid. "European Islamophobia Report". İstanbul: SETA, 2016.

Can, İsmail Özgür et al. "Travma Mağdurlarında Ruhsal Travma Bulguları (Mental Findings in Trauma Victims)". Archives of Neuropsychiatry, (2013): 230-236.

Cindoglu, Dilek. Headscarf Ban and Discrimination: Professional Headscarved Women in The Labor Market. İstanbul: TESEV Publications, 2011.

Çarmikli, Eyup Sabri. "Caught Between Islam and the West: Secularism in the Kemalist Discourse." $\mathrm{PhD}$ diss., UK: Westminster University, 2011.

Çayır, Kenan. Türkiye'de İslamcılık ve Íslami Edebiyat: Toplu Hidayet Söyleminden Yeni Bireysel Müslümanlıklara. İstanbul: İstanbul Bilgi Üniversitesi Yayınları, 2008.

Derksen, Jan. Personality disorders: Clinical And Social Perspectives: Assessment and treatment based on DSM-IV and ICD-10. Chichester: John Willey and Sons Inc., 1995.

Dursun, Davut. Demokratikleşemeyen Türkiye. İstanbul: İşaret 
Yayınları, 1999.

Ekşi, Halil. "Başaçıkma, Dinî Başaçıkma ve Ruh Sağlığı Arasındaki İlişki Üzerine Bir Araştırma”, PhD diss., Bursa: Uludag University, 2001.

Ergül, Ergin: "Islamophobia and The Counter-Terrorism Strategies", IPHRC, 1-21, 2017.

Gülalp, Haldun. Kimlikler Siyaseti. İstanbul: Metis Yayınları, 2003.

Göle, Nilüfer. Modern Mahrem. İstanbul: Metis Yayınları, 1991.

Göle, Nilüfer. Melez Desenler: İslam ve Modernlik Üzerine. İstanbul: Metis Yayınları, 2008.

Hajjat, Abdellali and Mohammed, Maewan. Islamophobie: Comment les élites françaises fabriquent le probleme musulman. Paris: La Découverte, 2013.

"Islamophobia and Muslim Minorities Studies" CIGA (Center For Islam and Global Affairs), IMMS. Accessed: December 22, 2019. https://www.izu.edu.tr/en/ciga/aboutus/departments/islamophobia-and-muslim-minorities-studies(imms).

Işıker, Deniz: "Bir Zorunluluk Alanı Olarak İçerisi ve Dışarısı", Master diss., İstanbul: İstanbul Bilgi University, 2011.

Johnson, David R. and Westermeyer, Joseph. "Psychiatric Therapies Influenced by Religious Movements" in Psychiatry and Religion: The Convergence of Mid and Spirit. Ed. James K, Boehnlein. 87-108. Washington: American Psychiatric Press Inc., 2000.

Kokurcan, Ahmet and Özsan, Hüseyin Hamdi. "Travma Kavramının Psikiyatri Tarihindeki Seyri (The Course of The Trauma 
Concept Throughout the History of Psychiatry)", Kriz Dergisi (Journal of Crisis) 20, no 1 (2012): 19-24.

Koenig, Harold G. Weiner, Debra K. and Bercedis L. Peterson. "Religious Coping in the Nursing Home: A Biopsychological Model", The International Journal of Psychiatry in Medicine, 27/4 (1997): 365-376.

Köknel, Özcan. Depresyon: Ruhsal Çöküntü, İstanbul: Altın Kitaplar Yayınevi, 1989.

Krebs, Dennis and Blackman, Roger. Psychology: A First Encounter, San Diego: Harcourt Brace Jovanovich Publishers, 1988.

Kula, Naci. Bedensel Engellilik ve Dini Başa Çıkma. İstanbul: DEM Yayınları, 2005.

Özipek, B. Berat. "28 Şubat ve İslamcılar” in Modern Türkiye'de Siyasi Düşünce Cilt 6 Íslamcılık. Ed. Yasin Aktay, 640-651. İstanbul: İletişim, 2005.

Pargament, Kenneth I. The Psychology of Religion and Coping. New York: The Guilford Press, 1997.

Pargament, Kenneth I. and Brant, C. R. "Religion and Coping" in Handbook of Religion and Mental Health. Ed. Harold G. Koenig, 111-128. USA: Academic Press, 1998.

Pargament, K. I. et al., "Religion and the problem-solving process: Three styles of coping" Journal for the Scientific Study of Religion, 27/1, (1988) 90-104.

Pargament, K. I., et al., "Patterns of Positive and Negative Religious Coping with Major Life Stressors", Journal for the Scientific Study of Religion, 37/4 (1998) 710-711. 
"Religious Freedom Is it a Human Right to Wear a Hijab or Head Scarf as a Muslim Woman?", Professor Cerone International Human Rights Inst. Accessed July 10, 2019. https://www.academia.edu/3093167/Religious_Freedom_Is_it_ a_Human_Right_to_Wear_a_Hijab_or_Head_Scarf_as_a_Mus lim_Woman.

Solgun, Sertaç. "Menemen Olayları Sonrasından İkinci Dünya Savaşına Türkiye'nin İç Güvenliği (1931-1939).” PhD diss., İstanbul: İstanbul University, 2010.

Sullaway, Megan. "Psychological Perspective On Hate Crime Laws". Psychology, Public Policy and Law, 10 (2004): 250-292.

Tunahan, Özcan. "28 Şubat Süreci: Post-Modern Darbenin SosyoPolitik Dinamikleri ve Toplum Desteğii”. Bilgi Sosyal Bilimler Dergisi, 30 (Summer, 2015): 23-41.

$\mathrm{Xu}$, Jianbin. "Pargament's Theory of Religious Coping: Implications for Spiritually Sensitive Social Work Practice”. British Journal of Social Work, 46/5(July 2016): 1394-1410. 
